محددات استخدام تطبيقات المحاسبة الإدارية في المشروعات الصغيرة والمتوسطة العاملة في مصر - دراسة استكثافية.

د. د مروة حسن محمد حسان

مدرس المحاسبةـ كلية التجارة

جامعة المنصورة

ملخص الاراسة

تسعى الاراسة الحالية إلى المساهمة في تلبية الدعوة بإجراء المزيد من البحوث،

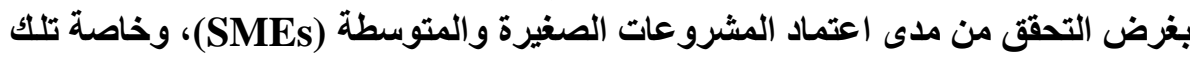

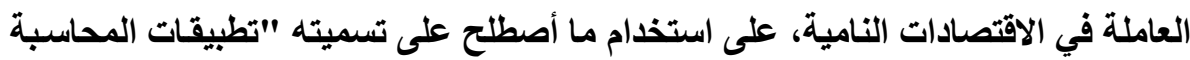

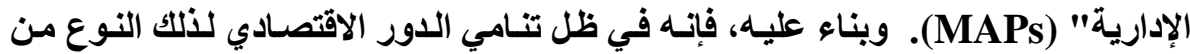

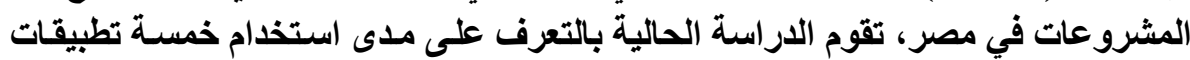

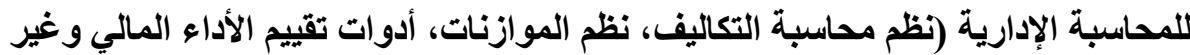

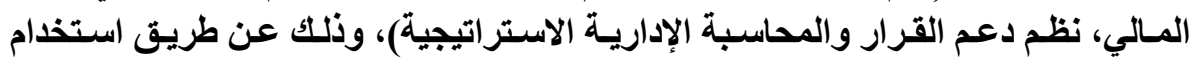

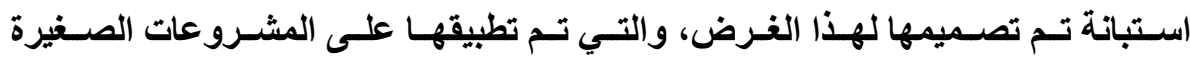

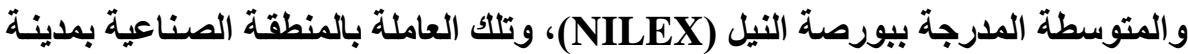

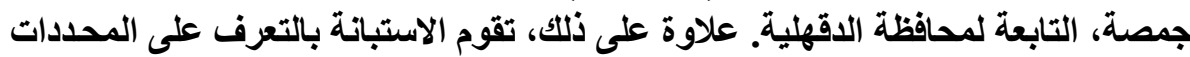

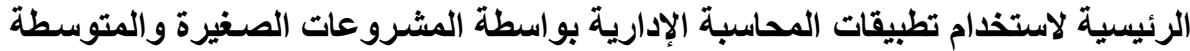

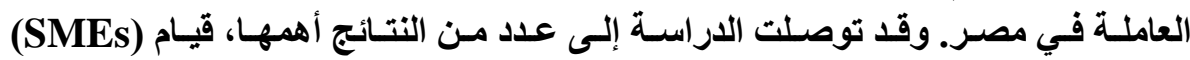
باستخدام تطبيقات المحاسبة الإدارية بلرجات متفاوتة. كنلك فئان الاعتمـاد على التطبيقات التات

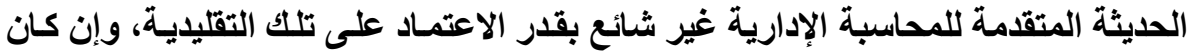

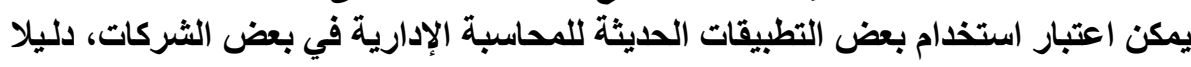

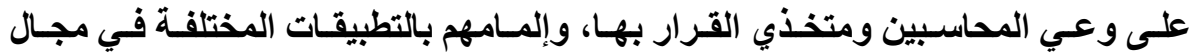

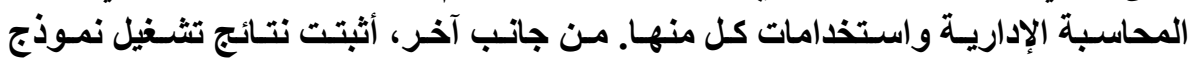

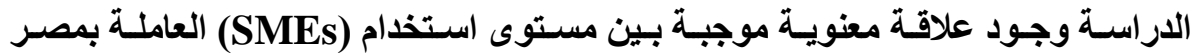

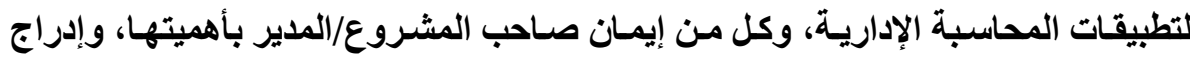

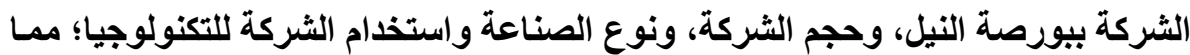

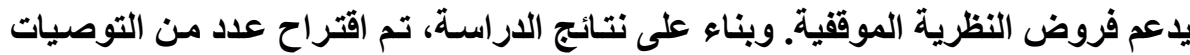

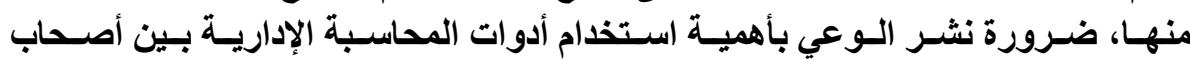

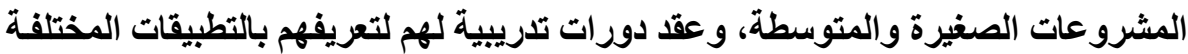

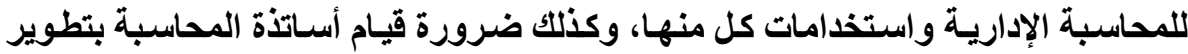

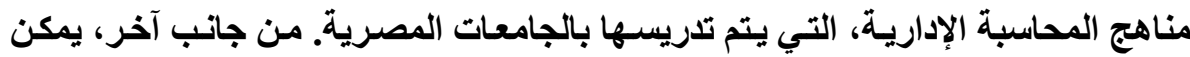

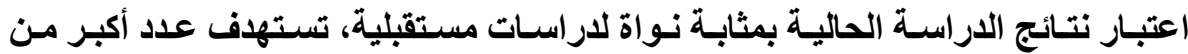

SMEs الكلمات المفتاحية: تطبيقات المحاسبة الإدارية، المشروعات الصغيرة والمتوسطة، بورصة النيل، المنطقة الصناعية بجمصة، الإلة النظرية الموقفية. 


\title{
Determinants of the Usage of Management Accounting Practices in Small and Medium Sized Enterprises Operating in Egypt-An Exploratory Study.
}

Dr. Marwa Hassaan ${ }^{1}$

\begin{abstract}
This study aims to respond to the recent call for more research, investigating the applicability of management accounting practices (MAPs), in small and medium sized enterprises (SMEs), particularly those operating in developing economies. Accordingly, stemming from escalating importance of SMEs in the development of the Egyptian economy, this study employs a questionnaire, to collect information about the extent of usage of five MAPs (namely, cost accounting systems, budgeting systems, financial and non-financial performance evaluation tools, decision support systems, and strategic management accounting systems), by SMEs that are listed on the Nile Exchange (NILEX), and those operating in Gamasa Industrial Zone, at Dakahlia Governorate. Additionally, the study questionnaire investigates the main determinants of usage of MAPs by SMEs operating in Egypt. The study results suggest that MAPs are employed by Egyptian SMEs at varying degrees. The reliance on advanced MAPs is not as common as traditional ones. However, employing advanced MAPs by some SMEs is a good sign that there is an awareness among accountants and owners in such SMEs about the types and uses of different MAPs. On the other hand, results generated through regression analysis, indicate that the extent of usage of MAPs is significantly and positively influenced by owner/manager belief in the importance of MAPs, listing status, company size, SME industry, and employment of technology within the firm. These results lend support to the contingency theory. Accordingly, the study made a number of recommendations including increasing awareness about the advantages of using MAPs among owners of SMEs and the need to provide training to inform them about management accounting different practices and uses of each, as well as the necessity of reviewing and developing management accounting modules that are taught by Accounting professors at Egyptian universities. On the other hand, the findings of this study could be considered as a starting point for further future research, targeting a greater number of Egyptian SMEs, as well as other MENA developing economies.
\end{abstract}

1 Dr. Marwa Hassan Mohamed Hassaan, Lecturer of Accounting, Faculty of Commerce, Mansoura University. 
Keywords: MAPs, SMEs, NILEX, Gamasa Industrial Zone, Contingency Theory.

\section{Introduction}

Recent years have witnessed an escalating concern worldwide, about the accounting practices in small and medium sized enterprises (SMEs). This concern is derived by the fact that SMEs represent up to $99 \%$ of the global business enterprises. Accordingly, SMEs play a pivotal role in fostering economic development in developed countries, such as the UK and the US (Lucas et al., 2013; Ahmed, 2017), as well on the level of developing countries such as Indonesia, Malaysia, Thailand and Egypt (Tambunan, 2008; Yoshino et al., 2015; Moukhtar, 2016; Ahmad, 2017).

On the level of the Egyptian context, approximately, $98 \%$ of manufacturing companies operating in Egypt take the form of SMEs, and produce about $60 \%$ of manufactured goods, with capital balance of less than 250,000 Egyptian pounds in more than $80 \%$ of such enterprises. Additionally, $70 \%$ to $80 \%$ of the Egyptian Gross Domestic Product (GDP) achieved by these enterprises, and up to $75 \%$ of the non-agriculture workforce is employed by SMEs (Loewe et al., 2013; FEP, 2016, Moukhtar, 2016).

Until now, there is no one common definition for SMEs in the Egyptian context. However, the review of the available definitions stated by the Egyptian organizational bodies (e.g., the Ministry of Investment, the Ministry of Industry, and the Social Development Fund), and the international institutions interested in the development of SMEs in Egypt, reveals that SMEs sector can be defined in terms of the number of employees (up to 100 employees), which is the most commonly used definition. SMEs can also be defined in terms of the size of capital and the balance of company assets, sales turnover or the industrial sector of the enterprise (FEP, 2016). On the other hand, according to the Egyptian Law number 141 that issued in 2004, to develop the micro (very small) and small enterprises sector, the micro enterprises are those with capital balance of less than 50,000 Egyptian pounds, and small enterprises are those with working 
capital from 50,000 to a million Egyptian pounds, and less than 50 employees. However, this law did not refer to medium sized enterprises.

The above discussion demonstrates the necessity of understanding the nature of SMEs that distinguishes them from large enterprises, and increases the possibility of their failure, given the complexity of current business environment. This implies that for SMEs to survive, they need to make a better usage of management accounting practices (MAPs). MAPs have the potential to integrate financial and nonfinancial information to support managerial functions by enabling SMEs to reduce waste, make better utilization of business resources, and more efficient monitoring and control of business operations, to sustain strategic, operational and financial performance. This point of view is supported by many researchers (e.g., Nandan, 2010; Lucas et al., 2013; Lavia Lopes and Hiebl, 2015; Ahmad, 2017; Azudin and Mansor, 2017; Cuzdriorean, 2017), who argue that SMEs need for MAPs, is not of less importance than that of large enterprises, as MAPs can help SMEs to achieve their targeted productivity, efficiency and hence profitability. Additionally, it is argued that the extent of usage of MAPs by SMEs depends on the contingent factors that constitute the internal and external environments in which the SMEs operate (e.g., Nandan, 2010; Azudin and Mansor, 2017; Cuzdriorean, 2017).

The review of prior literature investigating the employment of MAPs by SMEs, reveals that there is a shortage in this area of research, particularly on the level of developing countries, which have its distinguishing cultural, legal and organizational frameworks. Consequently, studying such an issue within the Egyptian context, is expected to provide an insight regarding the level of knowledge and usage of traditional and modern management accounting tools in the Egyptian SMEs sector. Furthermore, the results of this study are expected to highlight the main factors that enhance such usage, and influence the SME decision to select to apply specific MAPs in a developing country, that is struggling to develop the SMEs sector. Hence, this study responds to the calls of many researchers who claim that developing countries represent a unique context to explore the applicability of MAPs (Anderson and Lanen, 1999; Albu and Albu, 2012; Cuzdriorean, 2017). Consequently, the results of this study are expected to be of interest to academics, practitioners, 
professional bodies, policy makers, and organizational authorities, which are keen about developing the SMEs sector.

To achieve the purpose of this study, the remaining parts will be organized as follows. Section two indicates research questions, objectives and rationale. Section three provides theoretical background and literature review. Section four defines study hypotheses. Section five, depicts research methodology and finally, section six illustrates study results, conclusions, recommendations and implications for future research.

\section{Study Questions, Objectives and Rationale}

Given the fact that, there is an urgent need for more research that investigates the applicability of MAPs in SMEs, because of scarcity of evidence available in this regard (Uyar, 2010; Lucas et al., 2013; Armitrage et al., 2016; Azudin and Mansor, 2017). Also, due to the calls for investigating such an issue on the level of developing countries, as they have their special institutional and cultural contexts, that are expected to affect the influence of contingent factors on the SMEs decisions to use MAPs. On the other hand, based on the need to collect an evidence regarding such an issue on the level of the Egyptian context, as a promising transitional economy, that depends heavily on the SMEs sector to achieve the targeted economic development level, this study intends to answer the following research questions.

(1) What is the extent of usage of management accounting practices (MAPs) by Egyptian SMEs?

(2) Is there a significant difference in the extent of usage of MAPs by SMEs operating in Egypt, as classified in terms of listing status (listed on the Nilex/not listed); company size (small/medium) and industry group (industrial goods and services and automobiles/ food and beverages/ retail/ basic resources/ healthcare and pharmaceuticals/ chemicals)?

(3) What are the main determinants of usage of MAPs by SMEs operating in Egypt?

Based on the above mentioned research Questions, this study objectives can be stated as follows.

(1) To evaluate the overall extent of usage of MAPs by SMEs operating in the Egyptian context. 
(2) To assess whether there are significant differences in the extent of usage of MAPs among SMEs operating in Egypt, in terms of listing status, company size and industry.

(3) To identify the main determinants that influence the extent of utilization of MAPs in the Egyptian SMEs.

(4) To investigate the extent to which the contingency theory can explain the implementation of MAPs within SMEs operating in Egypt.

(5) To determine the main areas whereas MAPs need to be further developed to be suitable for implementation by SMEs operating in the Egyptian context, hence in other developing countries with similar institutional contexts.

This study is motivated by the need to contribute to management accounting literature, and small and medium sized enterprises related literature, as well as developing countries related literature, by providing an evidence from a developing country perspective, whereas business environment is more dynamic, complex and less predictable compared to developed countries, and where SMEs sector performance significantly affects economic growth. Hence, for SMEs to survive, they need to employ MAPs, to enhance the decision making process and support managerial functions. Results of the empirical analysis are expected to highlight the perceptions of SMEs regarding the applicability of management accounting practices in the Egyptian context. This can help in predicting perceptions of the users of MAPs in other similar contexts. In other words, the Egyptian context, is targeted in this study, as Egypt is an example of a middle income economy, that faces some challenges initiated by low level of economic diversification, high rate of unemployment, high level of imports and low level of exports, so improving the SMEs sector performance requires encouraging firms to adopt management accounting practices. On the other hand, given the scarcity of studies, that investigate the private sector development in the Middle East and North Africa (MENA) Region (Loewe et al., 2013), results of this study, although represent the status quo within the Egyptian context, can also help professional bodies and academics in identifying the most likely usable MAPs by SMEs operating in other MENA countries, and the reasons for their usage preferences. 


\section{Theoretical Background and Literature Review}

This section intends to provide a brief overview of the contingency theory, which provides a competent theoretical foundation that explains the main factors that influence the usage of MAPs by SMEs, and prior studies that mainly investigate the usage of MAPs by SMEs.

\section{3-1 The Contingency Theory}

The contingency theory attributes the employment of MAPs to a number of contingent elements, such as the environment, organizational structure, technology, firm size, market competition, cultural values, strategic view, and firm industry (Alleyne, 2011; Islam and Hu, 2012; Ajibolade, 2013; Oboh and Ajibolade, 2017). In other words, this theory explains the reasons behind differences in MAPs preferences among different business firms. This theory was firstly employed by Otly (1980), and claims that there is no single accounting practice that fits to all business firms under all situations. Accordingly, this theory is employed in the current study, whereas one of its major objectives is to identify the main determinants of MAPs selection by SMEs operating in the Egyptian context.

\section{3-2 Literature Review}

There is an escalating need to employ management accounting instruments in business firms, particularly SMEs to survive in the current complex business environment. Accordingly, since 2000, accounting researchers began to give attention to the importance of employing management accounting practices in SMEs, as a major economic sector, in almost all countries allover the world. This is reinforced by the view that employment of MAPs by SMEs, can support their managerial functions and organisation's structure, as well as strategic performance. Hence the correct implementation of MAPs is seen as having the potential to add value to SMEs, and support their continuity (Ittner and Larker, 2002; Nandan, 2010; Ahmad, 2017; Cuzdriorean, 2017). Follows a brief review of prior research investigated the adoption of different MAPs and the factors that affect such choice. 


\section{3-2-1 Studies Investigated the MAPs Employment}

The review of prior studies investigating the usage of MAPs by SMEs, reveals that, recently management accounting researchers pay more attention to investigating the extent of employment of modern and traditional management accounting practices specifically, cost accounting systems, budgeting systems, performance measures, decision support systems and strategic management accounting systems.

With respect to cost accounting systems and techniques, most researchers report that the majority of companies worldwide use cost accounting systems to gather information about the costs associated with the product, which help in pricing the product, evaluating the production process and control costs (Joshi, 2001; AbdelKader and Luther, 2006; Armitrage et al., 2016). Results generated by prior studies applied to developed and developing markets claim that absorption costing is the most commonly used costing system (e.g., Scherrer, 1996; Joshi, 2001; Szychta, 2002). Additionally, many studies (Joshi, 2001; AbdelKader and Luther, 2006) claim that variable/direct costing is a commonly used system. On the contrary, most researchers report that the use of activity based costing system is rare (Lamminmaki and Drury, 2001; Szychta, 2002; AbdelKader and Luther, 2006). For standard costing, De Zoysa and Kanthi Herath (2007) state that standard costing is widely used in both developing and developed contexts. Grosu et al. (2014), indicate that applying to the Romanian context, the most preferable cost accounting systems are job order costing, process costing and activity based costing, while the least preferable, is standard costing. However, applying to the UK, Brierley (2011) indicates that manufacturing SMEs operating in the UK, employ less sophisticated cost accounting systems.

With respect to budgeting systems, many researchers (e.g., Hansen and Van der Stede, 2004; Fruitticher et al., 2004) prove its usage to plan future performance and operations. Nik Ahmad et al. (2003) conclude that usage of flexible budget in the Malaysian context exceeds that in the UK and New Zealand. Ahmad and Zabri (2016), also report that flexible budgets are moderately used by Malysian SMEs, and that Zero-based budget is not widely used. With respect to timing, an annual budget is the most commonly used followed by monthly and rolling budgets in the Malaysian context (Ahmad, 2017). Szychta (2002) study results 
prove that a significant proportion of respondents are preparing operational budgets, followed by master budgets, while the preparation of other component budgets (e.g., sales, production and cost budgets) varies among respondents in the polish context. Another study (Davila and Foster, 2005), reports that starting SMEs prefer using operational and cash budgets. On the other hand, on the level of Canadian context, Armitrage et al. (2016), report that operating budgets are the most commonly used.

With respect to performance evaluation tools, in a study carried out by Hudson et al. (2001), to examine the usage of performance measures, results indicate that their choice is not in line with enterprise strategic dimension, and that financial measures are the most commonly used. This finding is also supported by another study (Sousa et al., 2006), applied to SMEs operating in the UK. Additionally, Ahmad (2017) reports that SMEs are significantly using financial measures such as operating system and sales growth, followed by cash flows. For non financial measures, on time delivery is widely used followed by number of customer complaints, manufacturing lead time and defect rate, with fewer respondents making use of employees based measures, return on investment and survey of customer satisfaction, with number of warranty claims being the least used measure (Ahmad, 2017). In another study targeting the Romanian context (Cuzdriorean, 2017), results reveal that benchmarking and performance reporting are used at a limited scale. On the other hand, in Canada, variance analysis is cited as the most widely used (Armitrage et al., 2016).

With respect to decision support systems, AbdelKader and Luther (2006) claim that cost-volume-profit, product profitability and customer profitability analyses, and models of stock control can help in making regular decisions. In a similar vein, Wu et al. (2007), hold that effective decision making is the most important factor in today's rapidly changing competitive environment. AbdelKader and Luther (2006) argue that for regular or shortterm decisions, management accountants can use cost-volumeprofit (CVP) analysis, product profitability analysis, customer profitability analysis, and stock control models. For longer-term capital investment decisions management accountants can produce and review accounting rates of return and payback periods as well as complex signals based on discounted cash flow. 
For capital budgeting techniques, they capture both non discounted and discounted approaches. Klammer et al. (1991) argue that internal rate of return and net present value analyses, are suitable under certainty conditions; while sensitivity analysis, rate of return, game theory, and Monte Carlo computer based simulation are more suitable under uncertainty conditions. With respect to long term decision support instruments, payback period is reported by many researchers as the most commonly used approach to evaluate investments (Lazaridis, 2004; AbdelKader and Luther, 2006; Hermes et al. 2007). With respect to, break even analysis, it is reported as one of the tools used by SMEs operating in Poland and the UK (Szychta, 2002; AbdelKader and Luther, 2006). Also break even analysis is reported as a common tool in India (Joshi, 2001) and in the UK (AbdelKader and Luther, 2006). Finally, applying to the Malaysian context, Ahmed (2017) demonstrates that decision support systems are moderately employed by SMEs, with short term systems being employed more frequently compared to long term ones.

Finally, with respect to strategic management systems, Cadez and Guilding (2008) argue that there are five dimensions to strategic management accounting; costing, planning, controlling and performance measurement, strategic decision making, competitor accounting and customer accounting. However, most studies claim that usage of strategic management accounting systems is not common (Joshi, 2001; AbdelKader and Luther, 2006; Guilding et al., 2006). On the other hand, AbdelKader and Luther (2006), applying to the UK state that more than $50 \%$ of respondents employ customer profitability analysis and competitive position analysis, compared to lower than $20 \%$ employ shareholder value analysis, industry analysis, and value chain analysis. Drury and Tayles (2006) conclude that, the product profitability technique is implemented by the majority of respondents. In a similar vein, Ahmad (2017) reports low implementation level of strategic management systems among SMEs operating in Malaysia.

The review of prior studies reveals that the extent of usage of different types of MAPs differs among countries, and from time to time within the same country, particularly on the level of developing countries. Hence, this justify carrying out the current study applying to the Egyptian context. 


\section{3-2-2 Studies Investigated the Determinants of MAPs Choice}

The review of prior studies investigating the different contingent factors that influence implementation of MAPs by SMEs (e.g., Davilla, 2005; Davilla and Foster, 2007; Albu and Albu, 2012; Hiebl et al., 2013; Azudin and Mansor, 2017; Cuzdriorean, 2017), reveals that there are many internal and external factors that have the potential to influence MAPs choices among SMEs. Applying to the US, the results reported by Davilla (2005), and Davilla and Foster (2007) indicate the existence of a significant positive relationship between the size of the enterprise, proxied by the number of employees, and the employment of a management control system. Additionally, Uyar (2010), supports the existence of a significant positive relationship between SME size and applying MAPs in Turkey, and Ahmad (2017) concludes that MAPs implementation by larger firms is significantly higher than in small ones, applying to the Malaysian context. In a similar vein, Albu and Albu (2012) report that size and capital type are the main determinants of usage of MAPs in the Romanian context. However, the study reveals the lack of influence of competition as concluded by $\mathrm{O}^{\prime}$ Connor et al. (2004). On the contrary, other studies (e.g., Luther and Longden, 2001; Waweru et al., 2004), report that competition enhances the usage level of MAPs applying to South Africa. With respect to the impact of technology, it is proved by Azudin and Mansor (2017), that operational technology positively affect the usage of MAPs by SMEs. Likewise, Szychta (2002) study results, support the claim that technology is one of the main factors that affect MAPs in Poland. With respect to owner belief in the importance of MAPs, it is proved that it affects the extent of his/her support to applying such practices (Brown et al., 2004). With respect to the effect of accounting staff qualification, Collis and Jarvis (2002), and McChlery et al. (2004), conclude that qualified accountants influence the development of MAPs within SMEs. This result is supported by Sousa et al. (2006), who claims that limited resources, lack of employee training and non-existence of well defined measures of performance, negatively affect reliance on MAPs. In a similar vein, Haldma and Laats (2002) state that, lack of qualified accountants, is an obstacle to applying modern MAPs. With respect to SME industry, it is argued that regardless of 
company size, company sector affects the framework within which it operates, hence its usage of MAPs (Uyar, 2010; Loewe et al., 2013; Messner, 2016). Accordingly, it is expected that SME industry affects its usage of MAPs. On the other hand, according to Cuzdriorean (2017), high adoption costs, absence of management commitment and financial constrains proved to be significant factors that restrict the usage of MAPs in SMEs. Finally, with respect to the influence of listing status, based on the findings of the majority of prior researchers, who argue that company size positively affects its level of implementation of MAPs, it can be argued that SMEs listed on the NILEX, are also more likely to adopt MAPs compared to non listed ones. This is supported on the grounds that, listed SMEs are most likely larger in size compared to non listed ones, and they are subject to more strict requirements from the NILEX.

The review of prior research investigating the main determinants of usage of MAPs by SMEs, reveals that their impact differs from one environment to another, and that there is a shortage in the number of studies that investigate the main factors that influence MAPs usage on the level of MENA region countries. Hence, this raises the need to carry out more studies, in order to fill this gap. Hence, this supports the need to carry out the current study, to evaluate MAPs in the Egyptian SMEs, and to identify the main contingent determinants that influence the extent of their usage.

\section{Study Hypotheses}

Based on the above discussion, current study hypotheses can be stated as follows.

1. MAPs are employed by SMEs operating in the Egyptian context.

2. There are significant differences between SMEs that are listed on the NILEX and those that are not, in the extent of usage of MAPs.

3. There are significant differences between small sized and medium sized companies in the extent of usage of MAPs.

4. There are significant differences among SMEs operating at different industries in the extent of usage of MAPs.

5. There are significant positive relationships between selected determinants and the extent of usage of MAPs by SMEs 
operating in Egypt. This hypothesis is divided into the following sub-hypotheses:

5-a: There is a significant positive relationship between the intensity of competition and the extent of usage of MAPs.

5-b: There is a significant positive relationship between the qualification of the SME accountant(s) and the extent of usage of MAPs.

5-c: There is a significant positive relationship between SME owner/manager belief in the importance of MAPs and the extent of usage of MAPs.

5-d: There is a significant positive relationship between SME employment for technology and the extent of usage of MAPs.

5-e: There is a significant positive relationship between the appropriateness of MAPs to the SME and the extent of their usage.

5-f: There is a significant positive relationship between the SME industry and the extent of usage of MAPs.

5-g: there is a significant positive relationship between the SMEs listing status and the extent of usage of MAPs.

5-h: there is a significant positive relationship between the SMEs size and the extent of usage of MAPs.

\section{Study Methodology}

\section{5-1 Research Instrument and Data Collection}

In order to achieve this study objectives, a questionnaire was employed to collect quantitative data for both descriptive and empirical analyses. Questionnaires are the most commonly used research instrument in investigating MAPs adoption by SMEs (e.g., AbdelKader and Luther, 2006; Ahmad, 2017; Ahmad and Zabri, 2017; Azudin and Mansor, 2017).The questionnaire is divided into three sections ${ }^{2}$. The first section is collecting information about the SME profile. The second section is collecting information about the extent of usage of MAPs by

\footnotetext{
${ }^{2}$ Please see the Appendix.
} 
SMEs operating in Egypt (cost accounting systems and techniques, budgeting systems, performance evaluation tools, decision support systems, strategic management accounting systems). The third section is collecting information about the perceptions of Egyptian SMEs regarding a number of contingent determinants, that are similar to SME industry, listing status and size, have the potential to affect the extent of usage of MAPs. As demonstrated by prior researchers, competition, accounting staff qualification, owner/manager belief in the importance of MAPs, technology employment, MAP appropriateness, in addition to some company characteristics (industry, company size and listing status), are important factors that have the potential to affect the usage of MAPs. The questionnaire employed three different types of scales; nominal (for identifying and classifying the characteristics of respondents), ordinal (using five point Likert scale to measure the extent of usage of MAPs and the determinants that influence such usage), and binary scales (yes/no questions) (Sekaran, 2004; Hair et al., 2007).

To get an assurance regarding the design and the focus of the study instrument, the survey design was guided by previous research in the area of management accounting, particularly in SMEs sector (e.g., Ahmad, 2017; Ahmad and Zabri, 2017; Azudin and Mansor, 2017). Additionally, a pilot study was conducted to refine the questionnaire by asking 5 experienced management accountants, and 5 management accounting academics to review the questionnaire and give their opinion. Based on their feedback, the questionnaire design was refined. Furthermore, the internal reliability of the questionnaire was checked using a Cronbach's Alpha which value was highly satisfactory $(0.767)$ as indicated in table (1).

Table (1) Reliability Statistics

\begin{tabular}{|c|c|}
\hline Cronbach's Alpha & N of Items \\
\hline .767 & 59 \\
\hline
\end{tabular}

With respect to target population for this study, it is limited to small and medium sized enterprises that are listed on the NILEX for the fiscal year 2017, and the ones that are operating in Gamasa Industrial Zone at Dakahlia Governorate. Firstly, a total of 32 questionnaires were mailed to all SMEs listed 
on the NILEX, which is established by the Egyptian exchange (EGX), supported by concerned authorities, to be the first small and medium enterprises exchange market in the MENA Region. Trading activities in the NILEX became effective since June, 2010. The mailed survey package incorporated in addition to the questionnaire, a covering letter that indicates this study purpose; both translated into Arabic. In addition, a prepaid envelope to return the questionnaire was attached. The postal package was directed to the manager of the accounting Department/the person in charge for preparing the firm accounts (as the most eligible respondent to complete the questionnaire). Followed the researcher made several phone calls to ask people in charge for public relations at NILEX listed firms, to follow up the mailed questionnaire in their firms, and make sure to return after being completed. Based on this procedure, 18 responses were returned from the NILEX listed firms (56\%). Accordingly, to have equivalent elements from Nilex and non NILEX SMEs, the researcher followed Hair et al. (2007) disproportionate stratified sampling approach, and has chosen $18(38 \%)$ out of the 47 SMEs operating in Gamasa Industrial zone. Additionally, for every industry, the researcher randomly selected a number of companies that equals the number of respondents in the same industry from the NILEX. The total sample size was considered satisfactory as it satisfies cost and time constraints, as well as statistical analyses minimum sample size constraint, which is $\mathbf{3 0}$ elements (Saunders, 2007). As SMEs operating in Gamasa Industrial Zone which is considered as a rural district, may get reluctant to respond to the questionnaire, as it requires some confidential information about the company, the researcher has decided to personally administer the questionnaire to provide assurance to respondents that the information collected is for research purposes only. This approach was very helpful, as it saved the time needed to collect the responses. Additionally, it provided assurance that respondents understand the questions, and that there is no room for misunderstanding from the side of respondents (Oboh and Ajibolade, 2017).

\section{5-2 Data Analysis and Regression Model}

Data collected using the questionnaires will be analysed using descriptive statistics. Additionally, through this data, the dependent and independent variables were generated for empirical analyses. Stepwise regression is employed for 
hypotheses testing, through multivariate statistical analysis. The regression Model can be stated as follows.

$$
\text { MAP Usage }=\beta_{0}+\beta_{1} X_{1}+\underset{\beta_{2} X_{2}+\beta_{3} X_{3}+\beta_{4} X_{4}+\beta_{5} X_{5}+\beta_{6} X_{6}+\beta_{7} X_{7}+}{\beta_{8} X_{8}+\varepsilon}
$$

Where:

$M A P$ Usage represents the dependent variable, and the variables from $\left(X_{1}\right.$ to $\left.X_{8}\right)$, represent the determinants of usage of MAPs (market competition; accounting staff qualification; owner belief in MAPs importance; technology employment; appropriateness; industry; listing status and company size respectively), and $\varepsilon$ represents the error term.

\section{Results, Conclusions and Implications for Future Research}

This section provides the main results obtained through statistical analyses, followed by a summary of the main conclusions and suggestions for future research.

\section{6-1 Statistical Analyses Results and Discussion}

The following part of this sub-section presents descriptive statistics for respondent SMEs profile, extent of usage of MAPs and the main determinants for MAP usage by SMEs operating in Egypt. Additionally, this sub-section presents the results of testing whether there are significant differences among SMEs in terms of their listing status; size; and industry. Finally, this sub-section indicates the results of multivariate regression analyses, to determine the main contingent factors that affect the extent of usage of MAPs by SMEs operating in the Egyptian context.

\section{6-1-1 Descriptive Statistics for SMEs Profile}

The purpose of this section is to provide background information about respondents, and obtain data for later statistical analyses. Table (2) demonstrates demographic information relating to the respondents. For better explanation, the data in the table is organized in terms of listing status, into companies not listed on the NILEX, which represents SMEs that are operating at Gamasa Industrial Zone; SMEs listed on the NILEX; and the total column. 
Table (2) SME Profile

\begin{tabular}{|c|c|c|c|c|c|c|}
\hline \multirow{3}{*}{ Element } & \multicolumn{6}{|c|}{ Listing Status } \\
\hline & \multicolumn{2}{|c|}{ Not Listed } & \multicolumn{2}{|c|}{ NILEX } & \multicolumn{2}{|c|}{ Total } \\
\hline & $\mathbf{N}$ & $\%$ & $\mathbf{N}$ & $\%$ & $\mathbf{N}$ & $\%$ \\
\hline \multicolumn{7}{|c|}{ Years of Operation } \\
\hline Less than 5 & 2 & 11 & $\mathbf{0}$ & $\mathbf{0}$ & 2 & 6 \\
\hline 5 to 10 & 5 & 28 & 7 & 39 & 12 & 33 \\
\hline More than 10 & 11 & 61 & 11 & 61 & 22 & 61 \\
\hline \multicolumn{7}{|c|}{ Industry } \\
\hline $\begin{array}{l}\text { Industrial goods and } \\
\text { services and automobiles }\end{array}$ & 6 & 33 & 6 & 33 & 12 & 33 \\
\hline Food and beverages & 3 & 17 & 3 & 17 & 6 & 17 \\
\hline Retail & 1 & 5 & 1 & 5 & 2 & 5 \\
\hline Basic Resources & 3 & 17 & 3 & 17 & 6 & 17 \\
\hline $\begin{array}{l}\text { Healthcare and } \\
\text { pharmaceuticals }\end{array}$ & 3 & 17 & 3 & 17 & 6 & 17 \\
\hline Chemicals & 2 & 11 & 2 & 2 & 4 & 11 \\
\hline \multicolumn{7}{|c|}{ Enterprise Type } \\
\hline Small & 8 & 44 & 7 & 39 & 15 & 42 \\
\hline Medium & 10 & 56 & 11 & 61 & 21 & 58 \\
\hline \multicolumn{7}{|c|}{ Operating Decisions } \\
\hline Owner & 17 & 94 & 8 & 44 & 25 & 69 \\
\hline Appointed Manager & 1 & 6 & 10 & 56 & 11 & 31 \\
\hline \multicolumn{7}{|c|}{$\begin{array}{l}\text { Holding a Degree in Accounting/Business Administration by } \\
\text { Owner/Manager }\end{array}$} \\
\hline Yes & 6 & 33 & 8 & 44 & 14 & 39 \\
\hline No & 12 & 67 & 10 & 56 & 22 & 61 \\
\hline
\end{tabular}

The results reported in Table (2) demonstrate that with respect to the years of operations, the majority of participants $(94 \%)$ are in business for periods exceeding 5 years, with $(61 \%)$ of them operating for more than $\mathbf{1 0}$ years. This result indicates that the majority of respondents are mature, well developed business firms, which in turn increases their likelihood to employ MAPs. With respect to SME industry/sector, the results illustrate that, the majority of respondents are belonging to industrial goods and services, and automobiles group (33\%), and the lowest number of respondents are from chemicals and retail industry groups $(11 \%$ and $5 \%$ respectively). With respect to the classification of the enterprise as small or medium sized, the results demonstrate that the majority of participants are medium sized (58\%), with $\mathbf{5 0}$ employees or more. This also can be considered as a good sign as larger companies are more likely to adopt MAPs, to better manage and control their resources. 


\section{6-1-2 Descriptive Statistics for Usage of MAPs}

Table (3) indicates the extent of usage of different groups of MAPs by SMEs operating in the Egyptian context. The extent of usage of broadly categorized management accounting practices (Cost Accounting Systems and Techniques; Budgeting Systems; Performance Evaluation Tools; Decision Support Systems; and Strategic Management Accounting Systems), was determined by asking respondents to the questionnaire, to choose the frequency of usage of a range of detailed practices using a five point Likert scale (Never, Rarely, Occasionally, Frequently, Very Frequently).

Table (3): Descriptive Statistics for Usage of Different MAPs

\begin{tabular}{|l|c|c|}
\hline \multicolumn{1}{|c|}{ N=36 } & Mean & $\begin{array}{c}\text { Std. } \\
\text { Deviation }\end{array}$ \\
\hline Cost Accounting Systems and Techniques & $\mathbf{3 . 5 7 7 2}$ & .52374 \\
\hline Budgeting systems & $\mathbf{3 . 1 9 6 8}$ &. $\mathbf{7 5 8 0 7}$ \\
\hline Performance Evaluation Tools & $\mathbf{3 . 4 1 4 5}$ & $\mathbf{. 6 9 4 4 5}$ \\
\hline Decision Support Systems & $\mathbf{3 . 7 1 5 3}$ &. $\mathbf{7 3 4 7 3}$ \\
\hline Strategic Management Accounting Systems & $\mathbf{3 . 2 0 2 0}$ & $\mathbf{. 9 0 8 6 0}$ \\
\hline
\end{tabular}

The results depicted in Table (3) indicate that the majority of participants use cost accounting systems and techniques frequently. This implies that SMEs operating in Egypt are aware about the importance of employing cost accounting systems and techniques in obtaining more accurate cost related information. The questionnaire required the respondents to determine the extent of usage of 8 different cost accounting systems and techniques (batch costing, process costing, operation costing, multiple/composite costing, marginal costing, standard costing, direct costing, and absorption costing). Responses indicated that individual costing MAPs are used at varying degrees. With respect to batch costing, standard costing and direct costing, the majority of respondents $(36.1 \% ; 33.3 \% ; 61.1 \%$ respectively) indicated that they use them occasionally. With respect to process, operation, marginal and absorption costing the majority of respondents $(30.6 \% ; 55.6 \% ; 41.7 \% ; 36.1 \%)$ indicated that they use them frequently. However, with respect to usage of multiple (composite) costing, the majority of respondents $(30.6 \%)$ indicated that they use them rarely. In general terms, it can be concluded that, SMEs operating in Egypt are familiar with the majority of practices headed by cost accounting systems and techniques. 
With respect to budgeting systems, results indicate that not all budgeting practices are widely used by SMEs operating in Egypt on a frequent bases (mean=3.2). This may be attributed to unfamiliarity with some budgeting practices (e.g., cash flow budget, financial position, monthly and continuous-rolling budget). Additionally, this can be attributed to some extent to the lack of awareness among many SMEs operating in Egypt regarding the importance of preparing different types of budgets to help in approximating future expected financial results and cash flows, to plan their operations in the way that is expected to achieve the required results. This may be a consequence of the high level of uncertainty shaping business environment in developing markets, which may cause some SMEs to think about some budgeting practices as time and effort consuming. On the level of individual budgeting systems, responses indicated that individual budgeting systems, are used at varying degrees. Sales, purchasing, production, cost-volume-profit (C.V.P) analysis, annual budgets and flexible budget are used very frequently by the majority of respondents $(58.3 \% ; 58.3 \% ; 38.9 \% ; 3.6 \%, 75 \%$ and $33.3 \%$ respectively). However, cash flow budget is proved to be used occasionally by the majority of respondents $(33.3 \%)$. For financial position budget and monthly budget, the majority of respondents rarely prepare $(33.3 \% ; 33.3 \%$ respectively). Meanwhile, the majority of respondents $(50.8 \% ; 38.9 \%)$ indicated that they never prepare continuous rolling budgets, or use zerobased budgeting respectively. In light of high frequent usage of flexible budgets, it can be said that the high level of uncertainty in developing countries, increase the importance of usage of flexible budgets.

With respect to performance evaluation tools, the results depicted in Table (3) indicate that the majority of participants use performance evaluation tools to some extent at frequent basis (mean=3.4). The respondents were asked to choose among a range of financial and nonfinancial performance measures; whereas nonfinancial measures are classified into customer related, operation related and employee related. On the level of individual performance measures, results indicate that they are used at varying degrees. For financial measures, sales growth has been selected by the majority of respondents $(58.3 \%)$ as very frequently used measure, followed by return on investment (used frequently by $41.7 \%$ of respondents). However, the remaining financial 
measures are used occasionally by the majority of respondents. On the other hand, for non-financial measures, results indicated that, the only used measure on frequent basis by the majority of respondents is the defect rate which is an operation related measure $(33.3 \%)$. Inversely, the majority of respondents $(47.2 \%)$ indicated that they never use the number of warranty claims which is a customer related measure. The remaining types of nonfinancial measures, were chosen by the majority of respondents as being prepared occasionally. Accordingly, it can be concluded that financial measures are more widely used by SMEs compared to non-financial ones, and non-financial measures are more operation focused and internal process oriented, than being customer or employee oriented.

With respect to Decision Support Systems, results indicate that both short term and long term analyses tools are employed by SMEs on frequent basis. This means that the majority of SMEs are aware about the importance of employing modern management accounting tools to guide decision making in the short and long runs, specifically when operating in a business environment characterized by high levels of uncertainty. The responses indicated that product profitability analysis represents the most widely used short term decision support tool, that is used by the majority of respondents $(\mathbf{5 2 . 8 \%})$ at frequent basis. On the other hand, payback was the most widely used long term decision support tool on frequent basis by a significant number of respondents $(\mathbf{5 2 . 8 \%})$.

Finally, with respect to usage of Strategic Management Accounting Systems, results reported in Table (3), indicate that they are used occasionally by the majority of respondents $($ mean= 3.20). This result is expected, as employing advanced management accounting tools, is more costly and require training. Hence, such tools are more likely to suit large firms than small and medium sized ones. On the level of individual tools, product demand followed by value chain analysis were the only frequently used practices by the majority of respondents $(41.7 \%$ and $30.6 \%$ respectively).

To sum up, the above discussion of the extent of usage of different MAPs by SMEs operating within the Egyptian context on group and individual levels, reveals that, SMEs operating in Egypt are employing different MAPs at varying degrees. These 
findings support those of prior researchers (e.g., Grosu et al., 2014; Ahmad and Zabri, 2016; Armitage et al, 2016; Ahmad, 2017; Azuden and Mansor, 2017; Cuzdriorean, 2017). Additionally, it is noticed that, although traditional MAPs are the most commonly employed, advanced MAPs also employed by some respondents. This implies that, the extent of employing different types of MAPs is not mainly influenced by its degree of sophistication. This can be attributed to the flexibility of management accounting tools, which gives SMEs the opportunity to choose the most suitable tools according to their needs, as such practices are not uniform. This point of view agrees with that provided by Azudin and Mansor (2017). Additionally, it can be considered as a good sign of awareness among accountants and owners in such SMEs about different types of MAPs and their uses. In the mean time, this can be attributed to the employment of qualified accounting staff by almost all SMEs, as well as, the flexibility of management accounting tools, which gives SMEs the opportunity to select the most suitable tools according to their needs. This in turn stimulates the need for further investigation of the main contingent determinants that influence usage of MAPs by SMEs operating in Egypt.

To further investigate whether there are significant differences between respondents that are attributed to their profiles (listing status, size and industry), Table (4) demonstrates the results using Kendall's tau-b test.

Table (4): Significant Differences in Usage of MAPs between Respondents in Terms of Listing Status, Size and Industry

\begin{tabular}{|c|c|c|c|c|}
\hline & Value & $\begin{array}{c}\text { Asymptotic } \\
\text { Standardized Errora } \\
\end{array}$ & $\begin{array}{c}\text { Approximate } \\
\text { Tb } \\
\end{array}$ & $\begin{array}{c}\text { Approximate } \\
\text { Significance }\end{array}$ \\
\hline \multicolumn{5}{|c|}{ Listing Status } \\
\hline Kendall's tau-b & .580 & .067 & 8.582 & .000 \\
\hline $\mathrm{N}$ of Valid Cases & 36 & & & \\
\hline \multicolumn{5}{|c|}{ Size } \\
\hline Kendall's tau-b & .428 & .107 & 3.915 & .000 \\
\hline $\mathrm{N}$ of Valid Cases & 36 & & & \\
\hline \multicolumn{5}{|c|}{ Industry } \\
\hline Kendall's tau-b & .353 & .100 & 3.563 & .000 \\
\hline N of Valid Cases & 36 & & & \\
\hline
\end{tabular}

Results indicated in Table (4) demonstrate that there are significant differences between SMEs in terms of listing status, firm size and industry group (Sig.<.01). With respect to listing status, results indicate that the extent of usage of MAPs by those 
listed on the NILEX exceeds that of non-listed SMEs (mean= 3.88 compared to 2.91). Additionally, medium sized SMEs use MAPs at greater extent compared to small sized (mean $=3.69$ compared to 2.98). Finally, with respect to industry type, health and pharmaceuticals ranked first with respect to the extent of usage of MAPs (mean= 4.01), followed by chemicals (mean=3.69), food and beverage $($ mean $=3.56)$, basic resources $($ mean $=3.32)$, industrial goods and services and automobiles (mean $=3.03)$, with retail industry ranked the last $($ mean $=\mathbf{2 . 8 7})$.

\section{6-1-3 Descriptive Statistics for Contingent Determinants of Usage of MAPs}

Table (5) demonstrates the descriptive statistics for the contingent determinants of usage of MAPs by SMEs operating in Egypt. As indicated earlier, the last section in the questionnaire investigates the effect of four factors that proved by prior research, discussed in Section (3), as contingencies for the usage level of MAPs (market competition; accounting staff qualification; owner/manager belief in the importance of using MAPs; employment of technology by SME).

Table (5): Descriptive Statistics for Contingent Determinants of Usage of MAPs

\begin{tabular}{|l|c|c|}
\hline \multicolumn{1}{|c|}{$\mathrm{N}=36$} & Mean & $\begin{array}{c}\text { Std. } \\
\text { Deviation }\end{array}$ \\
\hline Market Competition & 4.194 & .6242 \\
\hline Accounting Staff Qualification & 2.111 & 1.4693 \\
\hline Owner/Manager belief in the importance of using MAPs & 3.417 & .9673 \\
\hline Employment of Technology & $\mathbf{3 . 7 5 0 0}$ & $\mathbf{. 6 7 0 8 2}$ \\
\hline Appropriateness of MAP to the SME & $\mathbf{4 . 3 7 9 6}$ & $\mathbf{. 4 5 5 3 2}$ \\
\hline
\end{tabular}

Results presented in Table (5) promulgates that the majority of respondents see competition in the Egyptian context as intensive. This result is expected as $\mathbf{9 8 \%}$ of companies operating within the manufacturing sector are SMEs, hence competition is very strong among such companies. With respect to accounting staff qualification, all respondents indicated that they employ an accounting staff. Additionally, the majority of respondents indicated that their accountant(s) hold a Bachelor's Degree in Accounting. This means that the majority of company accountants have been taught management accounting modules 
during their study in the faculty of commerce. With respect to owner/manager belief in the importance of using MAPs, results indicate that a significant number of respondents consider their owners/managers as believing in more than a moderate extent in the importance of employing MAPs in their businesses. This is considered as a good sign of awareness among SMEs owners/mangers, of how employing management accounting tools can help in improving company performance, hence this can increase their support to employing MAPs in their firms. With respect to SME employment of technological advances in their firms, the majority of respondents indicated that they employ manufacturing technologies to a high extent. This in turn, is expected to enhance dependence on MAPs. Finally, with respect to respondents' opinion regarding the factors that are considered in their assessment of the degree of appropriateness of MAPs to their firms; the majority of respondents considered reasonable usefulness, ease of applying, reasonable implementation cost, nature of firm operations, familiarity with MAP and being required by an external party as leading factors. Being required by an external party was cited by the majority of respondents, as the most significant factor in assessing the appropriateness of MAP to their firms. For instance, banks may require some information that be produced through the usage of MAPs, in order to evaluate the eligibility of SME to receive a loan.

\section{6-1-4 Regression Analysis}

Table (6) reports the results of stepwise regression analysis that is being employed in this study in order to determine the independent variables that influence the extent of usage of MAPs by SMEs operating in the Egyptian context. The researcher provided the SPSS with a list of independent variables that are expected to influence the SMEs decision to employ MAPs (market competition, accounting staff qualification, owner/manager belief in the importance of using MAPs, SMEs usage of technology, appropriateness of MAP, SME industry, listing status and firm size).

In order to check for multicollinearity, the researcher checked the results of the correlation matrix, which indicated that none of the correlation coefficients for independent variables exceeded (0.8). This in turn provided a proof that the problem of multicollinearity does not exist. To further check for absence of 
the problem of multicollinearity, the VIF and tolerance were reviewed and found to be within acceptable limits, as VIF for all variables remained below 10 and tolerances were found to be above 0.2 while running the regression model (Field, 2005).

Table (6) Multiple regression Results

\begin{tabular}{|c|c|c|c|c|c|c|c|}
\hline $\mathbf{R}$ & \multicolumn{2}{|c|}{ R Square } & $\begin{array}{l}\text { Adjusted } \\
\text { R Square }\end{array}$ & $\begin{array}{c}\text { Standard } \\
\text { Error of the } \\
\text { Estimate }\end{array}$ & $\mathbf{F}$ & \multicolumn{2}{|c|}{ Significance } \\
\hline .875 & \multicolumn{2}{|c|}{.765} & .759 & .33827 & 71.600 & \multicolumn{2}{|c|}{.000} \\
\hline \multirow{2}{*}{ Model } & \multicolumn{2}{|c|}{$\begin{array}{c}\text { Unstandardized } \\
\text { Coefficients }\end{array}$} & \multirow{2}{*}{\begin{tabular}{|c|}
$\begin{array}{c}\text { Standardized } \\
\text { Coefficients }\end{array}$ \\
Beta
\end{tabular}} & \multirow{2}{*}{$\mathbf{t}$} & \multirow{2}{*}{$\begin{array}{l}\text { Signifi } \\
\text { cance }\end{array}$} & \multicolumn{2}{|c|}{$\begin{array}{l}\text { Collinearity } \\
\text { Statistics }\end{array}$} \\
\hline & B & $\begin{array}{c}\text { Standard } \\
\text { Error }\end{array}$ & & & & $\begin{array}{c}\text { Tolera } \\
\text { nce }\end{array}$ & VIF \\
\hline Constant & .949 & .215 & & 4.414 & .000 & & \\
\hline $\begin{array}{l}\text { Owner/Manger Belief in } \\
\text { the Importance of MAPs }\end{array}$ & .284 & .057 & .399 & 4.969 & .000 & .399 & 2.505 \\
\hline \begin{tabular}{|l|} 
Listing Status \\
\end{tabular} & .551 & .094 & .406 & 5.852 & .000 & .536 & 1.866 \\
\hline Company Size & .271 & .087 & .197 & 3.137 & .004 & .653 & 1.532 \\
\hline Industry & .072 & .021 & .193 & 3.445 & .002 & .818 & 1.223 \\
\hline $\begin{array}{l}\text { Employment of } \\
\text { Technology }\end{array}$ & .148 & .070 & .144 & 2.105 & .044 & .552 & 1.812 \\
\hline
\end{tabular}

The results presented in Table (6) indicate the main contingent factors that are considered as the major predictors of the extent of usage of management accounting practices in small and medium sized enterprises operating in the Egyptian context. The results show that the adjusted $R^{2}=.759$ which implies that approximately $76 \%$ of variation in the extent of usage of MAPs by SMEs operating in the Egyptian context is explained by, owner/manger belief in the importance of MAPs, listing status, company size, SME industry and employment of technology within the company. Additionally, the model reaches statistical significance with $F=71.600$ and the significance $=.000(<.01)$. The results support the hypothesized positive relationship between the above mentioned factors and the extent of usage of MAPs by SMEs operating in Egypt (hypotheses, 5c;d;f;g;h). However, the results do not give support to the existence of significant relationships between the extent of usage of MAPs and market competition, qualification of the accounting staff, and appropriateness of MAPs to the SME (hypotheses, 5a;b;e). Accordingly, SMEs which owner/manger believe in the importance of employing different management accounting practices in improving decision making process, control, and 
overall company performance; SMEs that are listed on the NILEX; medium sized enterprises; and those that employ advanced technologies, are more likely to employ MAPs at a higher extent. Owner/manager who believes in the advantages of using MAPs, will support the use of management accounting tools to provide the information needed to better inform decision making process and development of business strategy. On the other hand, the reported results reflect the uncertainty and complexity that shape the business environment in developing countries. This in turn pushes listed companies, medium sized, and the ones that employ advanced manufacturing systems to increase their dependence on management accounting tools to get more detailed information about costs, financial and nonfinancial performance, to better plan and control their operations, in order to secure their continuity. Additionally, listed firms, larger ones and those using advanced manufacturing systems, are expected to have the resources required to implement management accounting practices specially advanced ones, which are more costly and require trained personnel, and sometimes require buying expensive software packages. Hence, these findings support the contingency theory claims, and support its competency in identifying the main determinants of usage of MAPs by SMEs operating in developing countries in general and in the Egyptian context in particular. In addition, these findings support the argument highlighted by prior researchers applying to other environments, that the extent of usage of MAPs is influenced by a number of contingent factors (e.g., AbdelKader and Luther, 2006; Uyar, 2010; Albu and ALbu, 2012; Hiebl et al., 2013; Lavia L_opez and Hiebl, 2015; Azudin and Mansor, 2017; Cuzdriorean, 2017).

\section{6-2 Study Conclusions}

This study aimed to investigate the extent of usage of management accounting practices by small and medium sized enterprises operating in the Egyptian context, and its main determinants. A questionnaire survey was employed to reach that end applying to two groups of SMEs, those listed on the NILEX (the Egyptian exchange for SMEs) and the ones operating in Gamasa Industrial Zone at Dakahlya Governorate.

The main study findings and conclusions can be summarized as follows. 
-The majority of participants use cost accounting systems and techniques frequently. Accordingly, it can be concluded that, SMEs operating in Egypt are familiar with cost accounting systems and techniques, and employ them to obtain more accurate cost related information.

- The majority of participants are not using budgeting practices on a frequent bases. This may be attributed to unfamiliarity with some budgeting practices. Additionally, this can be attributed to some extent to the lack of awareness among many SMEs operating in Egypt, regarding the importance of preparing different types of budgets, to help in approximating future expected financial results and cash flows, to plan their operations in a way that is expected to achieve the required results.

- The majority of participants are not using performance evaluation tools at frequent basis. Additionally, results reveal that financial measures are more widely used by SMEs compared to non-financial ones, and that non-financial measures are more operation focused and internal process oriented, than being customer or employee oriented.

- Decision Support Systems, both short term and long term ones are employed by SMEs on frequent basis. However, Strategic Management Accounting Systems, are employed by SMEs to some extent.

- Traditional MAPs are more widely used compared to advanced ones. However, employing some of the advanced MAPs by some participants, reflects their awareness about different management accounting practices and their uses. Accordingly, it can be concluded that, the extent of employing different types of MAPs is not mainly influenced by its degree of sophistication. In the mean time, this can be attributed to the employment of qualified accounting staff by almost all SMEs, as well as, the flexibility of management accounting tools, which gives SMEs the opportunity to select the most suitable tools according to their needs.

- There are significant differences between respondents that are attributed to their profiles (listing status; size; industry group). Companies listed on the NILEX; medium sized; working in sophisticated industries like health and pharmaceutical 
industry, are using MAPs at greater degrees compared to nonlisted SMEs; small sized; those working in industries that are not likely to employ advanced technologies like retail industry.

- The majority of respondents considered competition they face in the market as intensive, and declared that appropriateness of MAPs to the SME, is also considered as a major contingent determinant of their extent of usage of MAPs.

- Regression analysis results reveal that, owner/manger belief in the importance of MAPs, listing status, company size, SME industry, and employment of technology within the firm, as the main determinants of the extent of usage of MAPs by Egyptian SMEs.

\section{6-3 Study Recommendations and Implications for Future Research}

This study provides some original findings relating to the extent of usage of MAPs by SMEs operating in Egypt, as one of the most promising developing economies, whereas SMEs represent a major contributor to its GDP, and a main employer to the majority of Egyptian workforce. Additionally, this study contributes to the existing literature that employ contingency theory to discover the significant contingent factors that influence the adoption of MAPs in SMEs.

Based on this study findings, it is recommended that policy makers in Egypt should provide training to the owners of SMEs, to increase their awareness about the different management accounting tools, and the advantages of applying them, to improve the efficiency and effectiveness of managing their firms and secure their survival. Additionally, Accounting academics should review and develop management accounting modules, to provide the graduates with the knowledge and capabilities needed to apply MAPs. On the other hand, the findings of this study could be considered as a starting point for further future research, targeting evaluation of management accounting practices among a greater number of Egyptian SMEs, as well as among other developing economies. 
Given the findings of this study, the researcher recommends the following for future research.

- Investigating the perceptions of the decision makers in SMEs, regarding the importance of implementing different MAPs.

- Investigating the impact of applying traditional and modern MAPs on the performance of SMEs using panel data.

- Applying the current study to all SMEs operating at different Egyptian governorates.

- Applying the current study to other countries in the Middle East and North Africa (MENA) and comparing the results.

- Investigating the impact of a greater range of contingent factors, and comparing the impact of internal and external ones on the implementation level of different MAPs.

- Employing other research tools such as carrying out interviews or case studies to get more in depth details.

\section{References}

Abdel-Kader, M. and Luther, R. (2006), "Management Accounting Practices in the British Food and Drinks Industry", British Food Journal, Vol. 108(5): 336-357.

Ahmad, K. (2017), "The Implementation of Management Accounting Practices and its Relationship with Performance in Small and Medium Enterprises", International Review of Management and Marketing, Vol.7(1): 342-353.

Ajibolade, S.O.(2013), "Drivers of Choice of Mnagmet Accounting System Designs in Manufacturing Companies in Nigeria", Global Journal of Accounting, Vol.3(1): 132-149.

Albu, N. and Albu, C. N. (2012) "Factors Associated with the Adoption and Use of Management Accounting Techniques in Developing Countries: The Case of Romania", Journal of International Financial Management and Accounting, vol. 23(3): 245-276.

Alleyne, P., and Weekes-Marshall, D. (2011), "An Exploratory Study of Management Accounting Practices in Manufacturing Companies in Barbados", International Journal of Business and Social Science, Vol.2(9):49-58.

Anderson, S. and Lanen, W. (1999) "Economic Transition, Strategy and the Evolution of Management Accounting Practices: 
The Case of India", Accounting, Organizations and Society, Vol.24(5-6): 379-412.

Armitage, H., Webb, A. and Glynn, J. (2016). "The Use of Management Accounting Techniques by Small and Medium-Sized Enterprises: A Field Study of Canadian and Australian Practice", Accounting Perspectives, Vol. 15(1):31-69.

Azudin, A. and Mansor, N. (2017),"Management Accounting Practices of SMEs: The Impact of Organizational DNA, Business Potential and Operational Technology", Asia Pacific Management Review.Avaialble:https://www.sciencedirect.com/science/article/pii /S1029313216300148. Accessed 25/12/2017.

Brierley, J.A. (2011), "A Comparison of the Product Costing Practices of Large and Small to Medium-Sized Enterprises: A Survey of British Manufacturing Firms, International Journal of Management, Vol. 28(4): 184-193.

Brown, A., Booth, P. and Giacobbe, F. (2004), "Technological and Organizational Influences on the Adoption of Activity-Based Costing in Australia", Accounting and Finance, Vol. 44 (3): 329356.

Cadez, S. and Guilding, C. (2008),"An Exploratory Investigation of an Integrated Contingency Model of Strategic Management Accounting", Accounting, Organizations and Society, Vol. 33:836863.

Collis, J. and Jarvis, R. (2002),"Financial Information and the Management of Small Private Companies", Journal of Small Business and Enterprise Development, Vol. 9(2):100-110.

Cuzdriorean, D.D. (2017), "The Use of Management Accounting Practices by Romanian Small and Medium-Sized Enterprises: A Field Study", Accounting and Management Information Systems, Vol.16 (2): 291-312.

Davila, A. and Foster, G. (2005), "Management Accounting Systems Adoption Decisions", Evidence and Performance Implications from Early-Stage/Startup Companies", The Accounting Review, vol. 80 (4): 1039-1068.

De Zoysa, A. and Kanthi Herath, S., (2007) "The Impact of Owner/Managers' Mentality on Financial Performance of SMEs in Japan: An Empirical Investigation", Journal of Management Development, Vol. 26 (7):652-666.

Drury, C. and Tayles, M. (2006),"Profitability Analysis in UK Organizations: An Exploratory Study", The British Accounting Review, Vol. 38: 405-425. 
Field, A. (2005), Discovering Statistics Using SPSS, (2 ${ }^{\text {nd }}$ Edition). London: Sage Publications.

First Equity Partners (2016), "Small and Medium Enterprises in Egypt, Definition, Landscape and Stakeholders", Available: http//firstequity-partners.com/wp-content/uploads/2017/06/SMEsin-Egypt.pdf. Accessed: 25/7/2017.

Fruitticher, L., Stroud, N., Laster, J. and Yakhou, M. (2004), "USA Budget Practices Case Studies", Managerial Auditing Journal, Vol. 20 (2):171-178.

Grosu, C., Almasan, A. and Circa, C. (2014), "The Current Status of Management Accounting in Romania: The Accountants Perception", Accounting and Management Information Systems,Vol. 13(3):537-558

Hair, J.F.J., Money, A.H., Samouel, P. and Page, M. (2007). Research Methods for Business. Chichester: John Wiley and Sons. Haldma,T. and Laats, K. (2002),"Contingencies Influencing the Management Accounting Practices of Estonian Manufacturing Companies", Management Accounting Research, Vol. 13: 379-400.

Hansen, S.C., Van der Stede, W.A.(2004),"Multiple Facets of Budgeting: An Exploratory Analysis", Management Accounting Research, Vol. 15: 415-439.

Hermes, N., Smid, P. and Yao, L. (2007). "Capital Budgeting Practices: A Comparative Study of the Netherlands and China", International Business Review, Vol. 16: 630-654.

Hudson, M., Smart, A. and Bourne, M. (2001), "Theory and Practice in SME Performance Measurement Systems", International Journal of Operations and Production Management, Vol. 21(8): 1096-1115.

Isalam, J. and Hu, H. (2012),"A Review of Literature on Contingency Theory in Mnagmerial Accounting", African Journal of Business Management, Vol. 6 (15): 5159-5164.

Ittner, C. and Larcker, D. (2002), "Empirical Managerial Accounting Research: Are We Just Describing Management Accounting Practice?", European Accounting Review, Vol. 11(4): 787-794.

Joshi, P. (2001) "The International Diffusion of New Management Accounting Practices: the Case of India", Journal of International Accounting, Auditing and Taxation, Vol. 10(1): 85-109.

Lamminmaki, D. and Drury, $C$. (2001), "A Comparison of New Zealand and British Product-Costing Practices", The International Journal of Accounting, Vol. 36 (3): 329-427. 
Lazaridis, I.T. (2004),"Capital budgeting practices: A survey in the firms in Cyprus", Journal of Small Business Management, Vol.42(4):427-433.

Loewe, M., Al-Ayouty, I, Altpeter, A., Borbein, L., Chantelauze, M., Kern, M., Niendorf, E. and Reda, R.(2013), "Which Factors Determine the Upgrading of Small and Medium-Sized Enterprises (SMEs)? The Case of Egypt", The German Development Institute in Cooperation with the Egyptian Center for Economic Studies (ECES).

López, O. L. and Hiebl, M. R. W (2015), "Management Accounting in Small and Medium-Sized Enterprises: Current Knowledge and Avenues for Further Research", Journal of Management Accounting Research, Vol.27(1): 81-119.

Lucas, M., Prowle, M., and Lowth, G. (2013), "Management Accounting Practices of UK Small-Medium-Sized Enterprises (SMEs)", Improving SME Performance through Management Accounting Education, Chartered Institute of Management Accountants UK, Vol. 9(4): 1-13.

Luther, R.G. and Longden, S. (2001), "Management Accounting in Companies Adapting to Structural Change and Volatility in Transition Economies: A South African Study", Management Accounting Research, Vol. 12: 299-320.

McChlery,S.,Meechan,L. and Godfrey, A.D.(2004),"Barriers and Catalysts to Sound Financial Management Systems in Small Sized Enterprises", Research Executive Summaries Series. CIMA, Vol.1(3).

Messner, M. (2016). "Does Industry Matter? How Industry Context Shapes Management Accounting Practice", Management Accounting Research: 103-111 (June).

Moukhtar, Y. (2016), "Small and Medium Enterprises in Egypt: Current State and Challenges", The Egyptian Center for Public Policy Studies.

Nandan, R. (2010), "Management Accounting Needs of SMEs and the Role of Professional Accountants: A renewed Research Agenda", Journal of Management Accounting Research, Vol. 8(1): 65-78.

Nik A., Sulaiman,M., and Alwi, N. (2003), "Are Budgets Useful? A Survey of Malaysian Companies", Managerial Auditing Journal, Vol. 18 (9):717-724.

Oboh, C.S. and Ajibolade, S.O. (2017),"Strategic Management Accounting and Decision Making: A Survey of the Nigerian Banks", Future Business Journal.Vol.3:119-133. 
O'Connor, N.G., Chow, C.W., and Wu, A. (2004),"The Adoption of Western Management Accounting/Controls in China's StateOwned Enterprises during Economic Transition", Accounting, Organizations and Society, Vol. 29(3/4): 349-375.

Otley, D. T.(1980),"The Contingency Theory of Management Accounting: Achievement and Prognosis", Accounting, Organizations and Society, Vol. 5(4): 413-428.

Saunders, M., Lewis, P. and Thornhill, A. (2009), Research Methods for Business Students, $\left(5^{\text {th }}\right.$ edition), Essex: Pearson Education Ltd.

Scherrer, G. (1996),"Management Accounting: A German Perspective", in Bhimani, A. (ed.), Management Accounting: European Perspectives, Oxford: Oxford University Press: 100-22.

Sekaran, U. (2004). Research Methods for Business, 4th ed., New York: John Wiley and Sons, Inc.

Sousa, S.D., Aspinwall, E.M., Rodrigues, A.G. (2006),"Performance Measures in English Small and Medium Enterprises: Survey Results. Benchmarking", An International Journal, Vol. 13(1/2): 120-134.

Szychta, A. (2002),"The Scope of Application of Management Accounting Methods in Polish Enterprises", Management Accounting Research, Vol.13: 401-418.

Tambunan, T. (2008), "SME Development, Economic Growth, and Government Intervention in A Developing Country: The Indonesian Story", Journal of International Entrepreneurship, Vol.6, 147-167.

Uyar, A. (2010), "Cost and Management Accounting Practices: A Survey of Manufacturing Companies", Eurasian Journal of Business and Economics, Vol.3(6):113-125.

Waweru, N.M., Hoque, Z. and Uliana, E. (2004),"Management Accounting Change in South Africa Case Studies from Retail Services", Accounting, Auditing and Accountability Journal, Vol. 17(5): 675-704.

Wu, J., Boateng, A. and Drury, C. (2007), "An Analysis of the Adoption, Perceived Benefits, and Expected Future Emphasis of Western Management Accounting Practices in Chinese SOEs and JVs", The International Journal of Accounting, Vol. 42: 171-185.

Yoshino, N., Taghizadeh-Hesary, F., Charoensivakorn, P., and Niraula, B. (2016), "Small and medium sized enterprise (SME) credit risk analysis using bank lending data: An analysis of Thai SMEs", Journal of Comparative Asian Development, Vol. 15(3): 383-406. 


\section{Appendix: Study Questionnaire}

Title: Determinants of the Usage of Management Accounting Practices in Small and Medium Sized Enterprises Operating in Egypt-An Exploratory Study.

This questionnaire has 3 sections. Section 1: SME Profile

\begin{tabular}{|c|c|c|c|c|}
\hline 1. & Years in operation (company age) & & & \\
\hline & Less than 5 years & [ ] ] & More than 10 years & {$[\mathrm{c}]$} \\
\hline & 5-10 years & [ ] ] & & \\
\hline 2. & Industry & & & \\
\hline & $\begin{array}{l}\text { Industrial goods and services and } \\
\text { automobiles }\end{array}$ & [ ] & $\begin{array}{l}\text { Healthcare and } \\
\text { Pharmaceuticals }\end{array}$ & [ ] \\
\hline & Food, and beverage & [ ] ] & Chemicals & [ ] ] \\
\hline & Retail & [ ] & Others (Please specify) & [ ] \\
\hline & Basic Resources & [ ] ] & 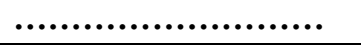 & \\
\hline 3. & Number of employees & & & \\
\hline & Please specify & [ ] & & \\
\hline 4. & $\begin{array}{l}\text { Separation of ownership and } \\
\text { control }\end{array}$ & & & \\
\hline & $\begin{array}{l}\text { Who is responsible for decision } \\
\text { making within the firm? }\end{array}$ & & & \\
\hline & Owner & [ ] & $\begin{array}{l}\text { An appointed } \\
\text { manager }\end{array}$ & [ ] \\
\hline 5. & $\begin{array}{l}\text { Educational background of } \\
\text { owner/manager }\end{array}$ & & & \\
\hline & $\begin{array}{l}\text { Does the owner/manager hold a } \\
\text { Degree in Accounting/business? }\end{array}$ & & & \\
\hline & Yes & [ ] ] & No & [ ] ] \\
\hline
\end{tabular}

Section 2: Extent of usage of management accounting practices (MAPs) by Egyptian SMEs

Part A: Usage of Cost Accounting Systems and Techniques

Please use the following scale for questions 6 and 7. Please circle your answer.

\begin{tabular}{|c|c|c|c|c|}
\hline Never & Rarely & Occasionally & Frequently & $\begin{array}{c}\text { Very } \\
\text { Frequently }\end{array}$ \\
\hline $\mathbf{1}$ & $\mathbf{2}$ & $\mathbf{3}$ & $\mathbf{4}$ & $\mathbf{5}$ \\
\hline
\end{tabular}

6. Please indicate to what extent the following cost accounting systems are employed in your firm

Job costing

/contract costing

\begin{tabular}{l|l}
1 & \\
\hline
\end{tabular}

(19

3




\begin{tabular}{|l|c|c|c|c|c|}
\hline Batch costing & $\mathbf{1}$ & $\mathbf{2}$ & $\mathbf{3}$ & $\mathbf{4}$ & $\mathbf{5}$ \\
\hline Process costing & $\mathbf{1}$ & $\mathbf{2}$ & $\mathbf{3}$ & $\mathbf{4}$ & $\mathbf{5}$ \\
\hline Operation costing & $\mathbf{1}$ & $\mathbf{2}$ & $\mathbf{3}$ & $\mathbf{4}$ & $\mathbf{5}$ \\
\hline $\begin{array}{l}\text { Multiple } \\
\text { (composite) } \\
\text { costing }\end{array}$ & 1 & 2 & 3 & 4 & 5 \\
\hline
\end{tabular}

7. Please indicate the extent to which the following costing techniques are
employed in your firm:
\begin{tabular}{|l|c|c|c|c|c|}
\hline Marginal costing & 1 & 2 & 3 & 4 & 5 \\
\hline Standard costing & 1 & 2 & 3 & 4 & 5 \\
\hline Direct (variable) costing & & & & & \\
\hline Absorption costing & & & & & \\
\hline
\end{tabular}

Part B: Usage of Budgeting Systems

\begin{tabular}{|c|c|c|c|c|c|}
\hline \multicolumn{6}{|c|}{$\begin{array}{l}\text { 8. Please indicate to what extent each of the following budgets is prepared in } \\
\text { your firm. }\end{array}$} \\
\hline Sales budget & 1 & 2 & 3 & 4 & 5 \\
\hline Purchasing budget & 1 & 2 & 3 & 4 & 5 \\
\hline Production budget & 1 & 2 & 3 & 4 & 5 \\
\hline Cash flow budget & 1 & 2 & 3 & 4 & 5 \\
\hline Financial position budget & 1 & 2 & 3 & 4 & 5 \\
\hline $\begin{array}{l}\text { Cost-volume-profit (CVP) } \\
\text { analysis }\end{array}$ & 1 & 2 & 3 & 4 & 5 \\
\hline
\end{tabular}

\begin{tabular}{|l|c|c|c|c|c|}
\hline 9. Please indicate how frequently the firm prepares its budgets \\
\hline Monthly & $\mathbf{1}$ & $\mathbf{2}$ & $\mathbf{3}$ & $\mathbf{4}$ & $\mathbf{5}$ \\
\hline Annually & $\mathbf{1}$ & $\mathbf{2}$ & $\mathbf{3}$ & $\mathbf{4}$ & $\mathbf{5}$ \\
\hline $\begin{array}{l}\text { Continually updated } \\
\text { (Continuous rolling budget) }\end{array}$ & 1 & 2 & 3 & 4 & 5 \\
\hline
\end{tabular}

10. Please indicate the extent of usage of each of the following types of budgeting models

\begin{tabular}{|l|l|l|l|l|l|}
\hline Flexible budget & $\mathbf{1}$ & $\mathbf{2}$ & $\mathbf{3}$ & $\mathbf{4}$ & $\mathbf{5}$ \\
\hline Incremental budget & $\mathbf{1}$ & $\mathbf{2}$ & $\mathbf{3}$ & $\mathbf{4}$ & $\mathbf{5}$ \\
\hline Zero-based budgeting (ZBB) & $\mathbf{1}$ & $\mathbf{2}$ & $\mathbf{3}$ & $\mathbf{4}$ & $\mathbf{5}$ \\
\hline
\end{tabular}

part C: Usage of Performance Evaluation Tools

Please use the following scale for question number 11. Please circle your answer.

\begin{tabular}{|l|l|l|l|l|}
\hline Never & Rarely & Occasionally & Frequently & $\begin{array}{l}\text { Very } \\
\text { Frequently }\end{array}$ \\
\hline 1 & 2 & 3 & 4 & 5 \\
\hline
\end{tabular}

11. Please indicate the extent to which each of the following performance measures are employed by your firm

\begin{tabular}{|l|l|l|l|l|}
\hline 1 & 2 & 3 & 4 & 5 \\
\hline
\end{tabular}




\begin{tabular}{|c|c|c|c|c|c|}
\hline Return on investment & 1 & 2 & 3 & 4 & 5 \\
\hline Variance analysis & 1 & 2 & 3 & 4 & 5 \\
\hline Sales growth & 1 & 2 & 3 & 4 & 5 \\
\hline Cash flows & 1 & 2 & 3 & 4 & 5 \\
\hline \multicolumn{6}{|l|}{ Non-financial measures } \\
\hline \multicolumn{6}{|l|}{ Customer related } \\
\hline $\begin{array}{l}\text { Number of customer } \\
\text { complaints }\end{array}$ & 1 & 2 & 3 & 4 & 5 \\
\hline $\begin{array}{l}\text { Survey of customer } \\
\text { satisfaction }\end{array}$ & 1 & 2 & 3 & 4 & 5 \\
\hline Number of warranty claims & 1 & 2 & 3 & 4 & 5 \\
\hline On-time delivery & $\mathbf{1}$ & 2 & 3 & 4 & 5 \\
\hline \multicolumn{6}{|l|}{ Operation related } \\
\hline $\begin{array}{l}\text { Manufacturing lead } \\
\text { time/cycle time }\end{array}$ & 1 & 2 & 3 & 4 & 5 \\
\hline Defect rate & 1 & 2 & 3 & 4 & 5 \\
\hline \multicolumn{6}{|l|}{ Employee related } \\
\hline Employee turnover & 1 & 2 & 3 & 4 & 5 \\
\hline Absentee rates & 1 & 2 & 3 & 4 & 5 \\
\hline
\end{tabular}

Part D: Usage of Decision Support Systems Please use the following scale for question number 12. Please circle your answer.

\begin{tabular}{|l|l|l|l|l|}
\hline Never & Rarely & Occasionally & Frequently & $\begin{array}{l}\text { Very } \\
\text { Frequently }\end{array}$ \\
\hline 1 & 2 & 3 & 4 & 5 \\
\hline
\end{tabular}

12. Please indicate the extent to which the following tools are used for decision making in your firm

\begin{tabular}{|l|c|c|c|c|c|}
\hline Short term analyses & 1 & 2 & 3 & 4 & 5 \\
\hline Break-even analysis & 1 & 2 & 3 & 4 & 5 \\
$\begin{array}{l}\text { Product profitability } \\
\text { analysis }\end{array}$ & 1 & 2 & 3 & 4 & 5 \\
\hline Stock control model & 1 & 2 & 3 & 4 & 5 \\
\hline $\begin{array}{l}\text { Customer profitability } \\
\text { analysis }\end{array}$ & \multicolumn{5}{|l|}{} \\
\hline Long term analyses & 1 & 2 & 3 & 4 & 5 \\
\hline Payback & 1 & 2 & 3 & 4 & 5 \\
\hline Accounting rate of return & 1 & 2 & 3 & 4 & 5 \\
\hline Internal rate of return & 1 & 2 & 3 & 4 & 5 \\
\hline Net present value &
\end{tabular}

Part E: Usage of Strategic Management Accounting Systems

Please use the following scale for question number 13. Please circle your answer.

\begin{tabular}{|l|l|l|l|l|}
\hline Never & Rarely & Occasionally & Frequently & $\begin{array}{l}\text { Very } \\
\text { Frequently }\end{array}$ \\
\hline 1 & 2 & 3 & 4 & 5 \\
\hline
\end{tabular}




\begin{tabular}{|l|c|c|c|c|c|}
\hline 13. To what extent do your firm employ the following tools \\
$\begin{array}{l}\text { Monitoring costs (product development costs: } \\
\text { installation, operation, support, maintenance } \\
\text { and disposal) }\end{array}$ & 1 & 2 & 3 & 4 & 5 \\
\hline $\begin{array}{l}\text { Strengths,weaknesses, opportunities and } \\
\text { threats (SWOT) analysis }\end{array}$ & 1 & 2 & 3 & 4 & 5 \\
\hline $\begin{array}{l}\text { Collecting information on competitor } \\
\text { operations and strategies }\end{array}$ & 1 & 2 & 3 & 4 & 5 \\
\hline Market share & 1 & 2 & 3 & 4 & 5 \\
\hline $\begin{array}{l}\text { Product demand (collecting information on } \\
\text { customers) }\end{array}$ & 1 & 2 & 3 & 4 & 5 \\
\hline $\begin{array}{l}\text { Understanding customer needs (collecting } \\
\text { information on the market) }\end{array}$ & 1 & 2 & 3 & 4 & 5 \\
\hline Balance score card (BSC) & 1 & 2 & 3 & 4 & 5 \\
\hline Product life cycle analysis & 1 & 2 & 3 & 4 & 5 \\
\hline Scenario analysis & 1 & 2 & 3 & 4 & 5 \\
\hline Benchmarking & 1 & 2 & 3 & 4 & 5 \\
\hline Value chain analysis & 1 & 2 & 3 & 4 & 5 \\
\hline
\end{tabular}

Section 3: Contingent Factors Affecting the Usage of MAPs by Egyptian SMEs.

Part A: Competition level in the market

Please use the following scale for question 14. Please circle your answer.

\begin{tabular}{|l|l|l|l|l|}
\hline $\begin{array}{l}\text { Not intensive } \\
\text { at all }\end{array}$ & Not intensive & $\begin{array}{l}\text { Slightly } \\
\text { intensive }\end{array}$ & Intensive & $\begin{array}{l}\text { Very } \\
\text { intensive }\end{array}$ \\
\hline 1 & 2 & 3 & 4 & 5 \\
\hline
\end{tabular}

\begin{tabular}{|l|l|l|l|l|l|l|}
\hline 14 & competition for the firm & 1 & 2 & 3 & 4 & 5 \\
\hline
\end{tabular}

Part B: Accounting staff qualification

Please tick the appropriate box for questions 15 and 16.

15. Does the firm have any accounting staff?

\begin{tabular}{|l|ll|}
\hline Yes & [ ] \\
\hline No & [ ] \\
\hline
\end{tabular}

If yes, please continue to question 16.

16. what is the highest educational qualification of your firm accountant?

\begin{tabular}{|l|l|l|l|}
\hline $\begin{array}{l}\text { High school } \\
\text { certificate in } \\
\text { commerce }\end{array}$ & [ ] & Bachelor's Degree in Accounting & [ ] \\
\cline { 1 - 2 } Master's degree & [ ] & Others (please specify) \\
\cline { 1 - 2 } PhD & [ ] …............................................................ \\
\hline CMA & [ ] & &
\end{tabular}

Part C: Owner/Manager Support to the Use of MAPs

Please use the following scale for question 17. Please circle your answer.

\begin{tabular}{|c|c|c|c|c|}
\hline Not at all & Low extent & $\begin{array}{l}\text { Moderate } \\
\text { Extent }\end{array}$ & High Extent & $\begin{array}{l}\text { Very High } \\
\text { Extent }\end{array}$ \\
\hline 1 & 2 & 3 & 4 & 5 \\
\hline
\end{tabular}




\begin{tabular}{|c|l|l|l|l|l|l|}
\hline 17 & $\begin{array}{l}\text { What is the extent to which } \\
\text { the firm owner believe in } \\
\text { the importance of MAPs? }\end{array}$ & 1 & 2 & 3 & 4 & 5 \\
\hline
\end{tabular}

Part D: Technology

Please use the following scale for question 18. Please circle your answer.

\begin{tabular}{|c|c|l|c|c|}
\hline Not Used & Low extent & $\begin{array}{l}\text { Moderate } \\
\text { Extent }\end{array}$ & High Extent & $\begin{array}{l}\text { Very High } \\
\text { Extent }\end{array}$ \\
\hline 1 & 2 & 3 & 4 & 5 \\
\hline
\end{tabular}

\begin{tabular}{|c|c|c|c|c|c|}
\hline \multicolumn{6}{|c|}{$\begin{array}{l}\text { 18. Please indicate the extent of usage of the following types of technologies in } \\
\text { your firm }\end{array}$} \\
\hline $\begin{array}{l}\text { Flexible manufacturing } \\
\text { system }\end{array}$ & 1 & 2 & 3 & 4 & 5 \\
\hline Advanced machinery & 1 & 2 & 3 & 4 & 5 \\
\hline
\end{tabular}

Part E: Assessment of MAPs Appropriateness to the Firm

Please use the following scale for question 18. Please circle your answer.

\begin{tabular}{|l|l|l|l|l|}
\hline Not at all & Low extent & $\begin{array}{l}\text { Moderate } \\
\text { Extent }\end{array}$ & High Extent & $\begin{array}{l}\text { Very High } \\
\text { Extent }\end{array}$ \\
\hline 1 & 2 & 3 & 4 & 5 \\
\hline
\end{tabular}

\begin{tabular}{|l|l|l|l|l|l|l|}
\hline 18. & $\begin{array}{l}\text { Indicate the extent to which } \\
\text { the following factors are } \\
\text { considered in the assessment } \\
\text { of the degree of } \\
\text { appropriateness of MAPs to } \\
\text { the firm }\end{array}$ & $\mathbf{1}$ & $\mathbf{2}$ & $\mathbf{3}$ & $\mathbf{4}$ & $\mathbf{5}$ \\
\hline Reasonable usefulness & & & & & \\
\hline Easy to apply & $\begin{array}{l}\text { Reasonable implementation } \\
\text { cost }\end{array}$ & & & & & \\
\hline & $\begin{array}{l}\text { Nature of firm operations } \\
\text { Familiarity with the } \\
\text { technique }\end{array}$ & & & & & \\
\hline $\begin{array}{l}\text { Required by an external } \\
\text { party (eg., the bank or } \\
\text { lending body) }\end{array}$ & & & & & \\
\hline
\end{tabular}

